\title{
Faktor-faktor yang Mempengaruhi Hasil Suplementasi Besi pada Ibu Hamil
}

\author{
Nanda Ilham Nur Kharisma, Aryu Candra \\ Bagian Gizi, Fakultas Kedokteran, Universitas Diponegoro
}

\begin{abstract}
Background: The prevalence of anemia in pregnant women in Indonesia is still high. Iron supplementation is one way to overcome anemia in pregnant women, but the mother's knowledge of iron folate supplementation, compliance, how to take iron folate supplementation and illnesses suffered by mothers are thought to influence the results of iron folate supplementation.

Objective: To determine the factors that influence the results of iron supplementation in pregnant women

Method: This was cross sectional study at the Halmahera Health Center during the January-November 2016. The study involved 42 pregnant women trimester II -III who had received iron folate supplementation and experienced anemia before receiving supplementation. Data on hemoglobin levels were obtained from laboratory tests, while data on knowledge, adherence, drinking and illnesses were obtained from questionnaire The results of the study were processed using univariate and bivariate analysis.

Results: The majority of pregnant women experienced increased hemoglobin levels after iron folate suplementation. There were influence of knowledge, adherence, and how to drink to increase hemoglobin levels after iron folate supplementation $(p<0.05)$. Folic and iron supplementation has a clinical effect in treating anemia in pregnancy because as many as $52.4 \%$ of women experience an increase in HB levels beyond the normal level $(\geq 11 \mathrm{mg} / \mathrm{dl})$. No results were obtained for the disease factor because all samples did not suffer from the disease with an onset of $>2$ weeks during pregnancy.
\end{abstract}

Keywords: pregnant women, anemia, iron folate supplementation, knowledge, adherence, how to drink, disease.

\section{ABSTRAK}

Latar Belakang: Prevalensi aaneia pada ibu hamil di Indonesia masih tinggi. Suplementasi besi merupakan salah satu cara mengatasi anemia pada ibu hamil, namun faktor pengetahuan ibu terhadap suplementasi besi folat, kepatuhan, cara minum suplementasi besi folat serta penyakit yang diderita oleh ibu diduga memengaruhi hasil suplementasi besi folat.

Tujuan: Mengetahui faktor- faktor yang memengaruhi hasil suplementasi besi pada ibu hamil

Metode: Penelitian ini menggunakan studi cross sectional di Puskesmas Halmahera selama periode Januari- November 2016. Penelitian ini melibatkan 42 ibu hamil trisemesterII -III yang sudah mendapatkan suplementasi besi folat dan mengalami anemia sebelum mendapatkan suplementasi. Data kadar hemoglobin diperoleh dari pemeriksaan laboratorium, sedangkan data pengetahuan, kepatuhan, cara minum dan penyakit yang diderita diperoleh dari wawancara kuesioner. Hasil penelitian diolah menggunakan analisis univariat dan bivariat.

Hasil : Mayoritas ibu hamil mengalami kenaikan kadar Hemoglobin paska suplemntasi besi folat. Terdapat pengaruh dari pengetahuan, kepatuhan, dan cara minum terhadap kenaikan kadar Hemoglobin paska suplementasi besi folat $(p<0,05)$. Suplementasi besi 
folat memiliki pengaruh klinis dalam mengatasi anemi adalam kehamilan karena sebanyak 52,4\% ibu mengalami kenaikan kadar HB hingga melampaui batas normal $(\geq 11 \mathrm{mg} / \mathrm{dl})$. Tidak didapatkan hasil pada faktor penyakit karena semua sampel tidak menderita penyakit dengan onset $>2$ minggu selama kehamilan

Kata kunci: ibu hamil, anemia, suplementasi besi folat, pengetahuan,kepatuhan, cara minum,penyakit.

\section{PENDAHULUAN}

Kesehatan ibu hamil yang merupakan indikator ke-5 dalam Millennium Development Goals (MDG) yang dicanangkan oleh WHO belum tercapai karena masih terdapat $37,1 \%$ ibu hamil yang mengalami anemia di Indonesia ${ }^{1}$. Suplementasi besi dianggap sebagai salah satu cara terbaik untuk mengatasi anemia pada ibu hamil, dan di Indonesia diberikan dalam bentuk tablet yang mengandung $60 \mathrm{mg}$ besi dan $0,25 \mathrm{mg}$ asam folat selama 90 hari ${ }^{2,3}$.

Persentase tertinggi cakupan ibu hamil mendapat 90 tablet Fe di Provinsi di Indonesia pada tahun 2014 terdapat di Provinsi Bali (95\%), DKI Jakarta (94,8\%), dan Jawa Tengah (92,5\%), sedangkan cakupan terendah terdapat di Provinsi Papua Barat (38,3\%), Papua $(49,1 \%)$, dan Banten $(61,4 \%){ }^{4}$. Persentase di Provinsi Jawa Tengah tahun 2014 sebesar 92,5\% sudah mengalami kenaikan bila dibandingkan dengan pencapaian tahun 2013 (90,74\%), dengan cakupan tertinggi dicapai Kabupaten Banyumas $(98,77 \%)$ dan terendah Kabupaten Rembang (86\%) ${ }^{5}$.

Pemberian suplementasi besi sudah dicanangkan oleh pemerintah sebagai salah satu cara menanggulangi anemia pada ibu hamil, namun pada kenyataannya belum terlihat adanya hasil yang signifikan terhadap suplementasi besi pada ibu hamil yang bisa dilihat dari prevalensi anemia yang masih tinggi pada hasil Riset Kesehatan Dasar (Riskesdas) 2013 yaitu 37,1\% di tingkat nasional ${ }^{1,6-10}$. Studi terhadap faktor - faktor yang mempengaruhi hasil suplementasi besi diharapkan dapat menjadi acuan bagi Puskesmas maupun Dinas Kesehatan di Kota Semarang dan Indonesia dalam menyusun kebijakan untuk menurunkan angka anemia pada ibu hamil secara keseluruhan.

\section{METODE}

Penelitian ini menggunakan metode cross - sectional dengan pengumpulan data menggunakan metode consecutive sampling, data kuantitatif menggunakan pemeriksaan laboratorium Hemoglobin darah dan data kualitatif menggunakan kuesioner dan wawancara mendalam. Variabel terikat dalam penelitian ini adalah hasil suplementasi besi. Hasil suplementasi besi didefinisikan sebagai kenaikan kadar Hemoglobin darah setelah selesai dilakukan suplementasi besi. Subyek dikategorika berhasil apabila terjadi kenaikan kadar Hemoglobin darah dan dikategorikan tidak berhasil apabila tidak terjadi kenaikan kadar Hemoglobin darah pasca suplementasi besi folat.

Variabel bebas dalam penelitian ini terdiri dari kepatuhan, pengetahuan, cara minum dan penyakit yang diderita. Kepatuhan konsumsi tablet besi folat 
diperoleh melalui perhitungan tablet yang tersisa. Subyek dikategorikan patuh apabila angka kepatuhannya mencapai $90 \%$ dan dikategorikan tidak patuh apabila angka kepatuhannya $<90 \%$. Pengetahuan ibu hamil adalah pengetahuan mengenai tablet besi folat dan anemia defisiensi besi. Pengetahuan ibu hamil diukur dengan presentase skor jawaban benar pada kuesioner. Skor pengetahuan dikategorikan baik apabila $>80 \%$ jawaban benar, cukup bila jumlah jawaban benar antara $60-80 \%$ dan kurang jika $<60 \%$.

Cara minum adalah waktu dan dengan apa ibu dalam meminum suplementasi besi folat, dengan cara yang dikategorikan benar adalah saat lambung kosong dan diminum dengan air putih atau air jeruk, sedangkan salah apabila diminum saat lambung terisi dan dengan selain air putih atau air jeruk. Variabel penyakit adalah penyakit yang diderita ibu selama suplementasi besi folat dengan onset $>2$ minggu.

\section{HASIL}

\section{Karakteristik Responden}

Tabel 1. Distribusi Sampel Penelitian

\begin{tabular}{lcc}
\hline \multicolumn{1}{c}{ Variabel } & Frekuensi (n) & Persentase (\%) \\
\hline Usia Ibu & \multicolumn{2}{c}{} \\
$<20$ tahun & 34 & 19,0 \\
$20-35$ tahun & 0 & 81,0 \\
$>35$ tahun & & 0 \\
Usia Kehamilan & 27 & 64,3 \\
$\quad$ Trimester II & 15 & 35,7 \\
$\quad$ Trimester III & & \\
Keberhasilan Suplementasi & 6 & 14,3 \\
$\quad$ Tidak Berhasil & 36 & 85,7 \\
Berhasil & & \\
Pengetahuan & 14 & 33,3 \\
Kurang & 19 & 45,2 \\
Sedang & 9 & 21,4 \\
Baik & & \\
Kepatuhan & 6 & 14,3 \\
Tidak Patuh & 36 & 85,7 \\
Patuh & & \\
Cara Minum & 11 & 26,2 \\
Salah & 31 & 73,8 \\
Benar & & \\
Penyakit Yang Diderita & 42 & 0 \\
Tidak Ada & 0 & \\
Ada & & \\
\hline
\end{tabular}


Penelitian ini menggunakan sampel sebanyak 42 ibu hamil yang terdiri dari 27 ibu hamil trimester II dan 15 ibu hamil trimester III yang sudah mendapatkan suplementasi besi folat dan menderita anemia (kadar Hemoglobin $<11 \mathrm{mg} / \mathrm{dl}$ ) sebelum suplementasi. Usia subjek terdiri dari $8 \mathrm{ibu}$ berusia $<20$ tahun dan $34 \mathrm{ibu}$ berusia 20 - 35 tahun. Tabel 1 menunjukkan bahwa sebagian besar ibu hamil mengalami keberhasilan dalam suplementasi besi, yang ditandai oleh kenaikan kadar Hemoglobin sebanyak 85,7\% dari total responden pasca suplementasi. Derajat pengetahuan ibu hamil mayoritas berada dalam kategori Sedang $(45,2 \%)$, serta sebagian besar ibu hamil sudah patuh dalam meminum suplementasi besi, yaitu sebanyak $85,7 \%$ ibu hamil. Sebagian besar ibu hamil $(73,8 \%)$ juga sudah meminum tablet suplementasi besi dengan benar, yaitu diminum dengan air putih atau air jeruk. Tidak ada ibu hamil yang menderita penyakit tertentu dengan onset selama $>2$ minggu.

\section{Rerata Kadar Hemoglobin dan Derajat Anemia pada Sampel}

Tabel 2. Distribusi Rerata Kadar Hemoglobin Sampel

\begin{tabular}{cccccc}
\hline Kadar HB & Range & Min & Max & Mean & Std.Dev \\
\hline Pra Suplementasi & 3,6 & 7.2 & 10,8 & 9.912 & 0,7096 \\
Pasca & 3,7 & 9,1 & 12,8 & 10,752 & 0,7639 \\
Suplementasi & & & & & \\
\hline
\end{tabular}

Tabel 2 menunjukkan rerata kadar Hemoglogin pada sampel, dengan kadar pra suplementasi besi folat terendah adalah $7,2 \mathrm{mg} / \mathrm{ld}$ dan tertinggi adalah $10,8 \mathrm{mg} / \mathrm{dl}$ dengan nilai mean $9,912 \mathrm{mg} / \mathrm{dl}$ serta kadar pasca suplemntasi terendah adalah $9,1 \mathrm{mg} / \mathrm{dl}$ dan tertinggi adalah $12,8 \mathrm{mg} / \mathrm{dl}$ dengan nilai mean $10,752 \mathrm{mg} / 1$

\section{Kategori Derajat Anemia Pra Suplementasi}

Tabel 3. Distribusi Derajat Anemia Pra Suplementasi

\begin{tabular}{ccc}
\hline Derajat Anemia (Hb dalam mg/d) & Frekuensi (n) & Persentase (\%) \\
\hline Ringan $(10,0-10,9)$ & 26 & 61,9 \\
Sedang $(7,0-9,9)$ & 16 & 38,1 \\
Berat $(<7,0)$ & 0 & 0 \\
\hline
\end{tabular}

Tabel 3 menunjukan distribusi derajat anemia pra suplementasi besi folat pada sampel, dengan jumlah terbanyak menderita anemia derajat ringan $61,9 \%$ dan sebanyak 38,!\% menderita anemia derajat sedang, serta tidak ada sampel yang dikategorikan sebagai anemia derajat berat. 


\section{Kategori Derajat Anemia Pasca Suplementasi}

Tabel 4. Distribusi Derajat Anemia Pasca Suplementasi

\begin{tabular}{ccc}
\hline Derajat Anemia $(\mathbf{m g} / \mathbf{d l})$ & Frekuensi $(\mathbf{n})$ & Presentase $\mathbf{( \% )}$ \\
\hline Tidak Anemia $(\geq 11)$ & 22 & 52,4 \\
Ringan $(10,0-10,9)$ & 13 & 30,9 \\
Sedang $(7,0-9,9)$ & 7 & 16,7 \\
Berat $(<7)$ & 0 & 0 \\
\hline
\end{tabular}

Tabel 4 menunjukkan distribusi derajat anemia pasca suplementasi pada sampel dengan jumlah terbanyak pada kategori tidak anemia 52,4\%, sebanyak $30,9 \%$ menderita anemia derajat ringan, dan sebanyak 16,7\% menderita anemia derajat sedang, serta tidak ada sampel yang dikategorikan anemia derajat berat.

\section{Analisis Bivariat}

Tabel 5. Hasil Analisis Fakto- faktor yang Memengaruhi Hasil Suplementasi Besi

\begin{tabular}{|c|c|c|c|c|c|}
\hline \multirow{3}{*}{ Faktor } & \multicolumn{4}{|c|}{ Hasil Suplementasi } & \multirow{3}{*}{$\mathbf{p}$} \\
\hline & \multicolumn{2}{|c|}{ Tidak Berhasil } & \multicolumn{2}{|c|}{ Berhasil } & \\
\hline & $\mathbf{n}$ & $\%$ & $\mathbf{n}$ & $\%$ & \\
\hline \multicolumn{6}{|l|}{ Pengetahuan } \\
\hline Kurang & 5 & 35,7 & 9 & 64,3 & 0,018 \\
\hline Sedang & 1 & 5,3 & 18 & 94,7 & \\
\hline Baik & 0 & 0 & 9 & 100 & \\
\hline \multicolumn{6}{|l|}{ Kepatuhan } \\
\hline Tidak Patuh & 3 & 50 & 3 & 50 & 0,007 \\
\hline Patuh & 3 & 8,3 & 33 & 91,7 & \\
\hline \multicolumn{6}{|l|}{ Cara Minum } \\
\hline Salah & 5 & 45,5 & 6 & 54,5 & 0,001 \\
\hline Benar & 1 & 3,2 & 30 & 96,8 & \\
\hline \multicolumn{6}{|l|}{ Penyakit } \\
\hline Tidak Ada & 6 & 14,3 & 36 & 85,7 & \\
\hline Ada & 0 & 0 & 0 & 0 & \\
\hline
\end{tabular}

Dari tabel 5 dapat diketahui bahwa terdapat hubungan bermakna antara pengetahuan, kepatuhan maupun cara minum tablet suplementasi besi dengan hasil suplementasi besi.

\section{PEMBAHASAN}

\section{Pengaruh Pengetahuan Ibu Terhadap Hasil Suplementasi Besi Folat}

Pengetahuan ibu adalah pengetahuan mengenai suplementasi besi folat dan anemia defisiensi besi yang diperoleh dengan menggunakan kuesioner. Hasil analisis data menunjukkan didapatkan adanya pengaruh antara 
pengetahuan ibu tentang suplementasi besi folat terhadap hasil suplementasi besi folat. Hal ini dapat dilihat dari nilai p sebesar 0,018 $(<0,05)$.

Sebagian besar ibu hamil masih memiliki tingkat pengetahuan terhadap suplementasi besi folat dalam kategori sedang, yaitu skor pengetahuan di antara nilai 60 - 79, dan 9 ibu yang mendapatkan skor baik. Hal ini dapat terjadi karena ibu kurang mendapatkan penjelasan tentang hal - hal penting yang berkaitan dengan suplementasi besi folat karena sebagian ibu menyampaikan bahwa hanya mendapatkan penjelasan singkat tentang suplementasi besi folat dari kunjungan ANC. Beberapa ibu juga memiliki kesalahpahaman tentang suplementasi besi folat bahwa suplementasi hanya diminum apabila merasa lemas dan lelah. Pada penelitian sebelumnya yang dilakukan oleh Budiarni, W (2012) di Puskesmas Halmahera didapatkan bahwa sebagian besar ibu hamil memiliki pengetahuan tentang suplementasi besi folat dalam kategori baik $(50,0 \%)^{10}$, sehingga dapat dikatakan bahwa tingkat pengetahuan ibu terhadap suplementasi besi folat mengalami penurunan. Penelitian serupa yang dilakukan di RSUD Arifin Nu'mang menunjukkan bahwa pengetahuan ibu hamil yang baik mengenai tablet besi folat akan mempengaruhi kepatuhan ibu hamil dalam mengkonsumsi tablet. Pengetahuan ibu hamil ini tidak hanya diperoleh dari pendidikan formal tetapi juga dapat diperoleh melalui penyuluhan dan sosialisasi yang dilakukan oleh petugas kesehatan ${ }^{18}$.

\section{Pengaruh Kepatuhan Ibu Terhadap Hasil Suplementasi Besi Folat}

Kepatuhan mengonsumsi suplemen besi folat diartikan sebagai persentase jumlah tablet suplemen besi folat yang dikonsumsi dengan jumlah tablet suplemen besi folat yang seharusnya dikonsumsi, yaitu sebanyak 90 tablet selama 90 hari.

Dari hasil pemeriksaan kepatuhan pada sampel didapatkan adanya pengaruh antara kepatuhan ibu dalam meminum suplementasi besi folat terhadap hasil suplementasi besi folat. Pada penelitian ini, didapatkan tingkat kepatuhan ibu dalam meminum suplemen besi folat sudah baik, yaitu $85,7 \%$ sudah meminum tablet dengan jumlah yang seharusnya, sehingga dapat disimpulkan bahwa terdapat peningkatan jika dilihat dari penelitian yang dilakukan oleh Rahmawati, F (2012) di Puskesmas Halmahera, yaitu didapatkan tingkat kepatuhan ibu hamil dalam meminum suplementasi besi folat sebesar $41,1 \%$ dan terjadi karena dalam meminum suplemen besi folat sebagian besar ibu merasa bahwa tablet berbau amis dan mengalami efek samping berupa mual ${ }^{17}$. 
Faktor pengetahuan berhubungan dengan kepatuhan karena pengetahuan merupakan domain yang sangat penting untuk terbentuknya perilaku. Perilaku akan memiliki dasar yang kuat jika didasari oleh pengetahuan. Pengetahuan yang diperoleh melalui pengindraan ibu hamil terhadap informasi kesehatan selama kehamilan akan berpengaruh terhadap perilaku ibu hamil dalam menjaga kesehatannya ${ }^{19}$.

\section{Pengaruh Cara Minum Suplemen Terhadap Hasil Suplementasi Besi Folat}

Cara minum diartikan sebagai kapan dan dengan apa ibu mengonsumsi suplemen besi folat, dengan kriteria cara minum benar apabila diminum saat lambung kosong dan diminum dengan air jeruk ataupun air putih. Hasil analisis cara minum suplementasi besi folat pada sampel menunjukkan bahwa terdapat pengaruh antara cara ibu meminum suplementasi besi folat terhadap hasil suplementasi besi folat. Faktor ini sangat berpengaruh dalam peningkatan kadar hemoglobin darah pasca suplementasi karena Vitamin $\mathrm{C}$ yang terkandung dalam air jeruk dapat mempercepat penyerapan dan transportasi zat besi dalam tubuh akibat dari peran Vitamin $\mathrm{C}$ dalam mobilisasi hemosiderin dalam limpa ${ }^{20}$, sedangkan konsumsi tablet besi folat bersama dengan air the dapat menghambat penyerapan zat besi hingga $60 \%{ }^{21}$.

\section{Pengaruh Penyakit yang Diderita Terhadap Hasil Suplementasi Besi Folat}

Pada penelitian ini, tidak didapatkan sampel yang menderita penyakit dengan onset > 2 minggu, sehingga pengaruh faktor penyakit terhadap hasil suplementasi besi folat tidak dapat dinilai.

\section{SIMPULAN}

Berdasarkan penelitian yang dilakukan, dapat disimpulkan bahwa faktor pengetahuan ibu terhadap suplementasi besi folat, kepatuhan ibu meminum suplementasi besi folat serta cara ibu meminum suplementasi besi folat mempengaruhi hasil suplementasi besi folat yang ditandai dengan kenaikan kadar Hemoglobin darah pasca suplementasi pada $85,7 \%$ sampel. Suplementasi besi folat juga memiliki pengaruh secara klinis untuk mengatasi anemia pada ibu hamil karena sebanyak 52,4\% ibu mengalami kenaikan kadar Hemoglobin darah hingga mencapai nilai normal ( $\geq 11 \mathrm{mg} / \mathrm{dl})$.

\section{SARAN}

Perlu penelitian lebih lanjut mengenai faktor - faktor yang mempengaruhi hasil suplementasi besi pada ibu hamil dengan faktor selain kepatuhan 
pengetahuan ibu terhadap suplementasi besi folat, cara minum dan penyakit yang diderita ibu dengan metode dan sampel yang lebih baik.

Perlunya program sosialisasi pra - kehamilan kepada ibu - ibu tentang anemia defisiensi besi pada kehamilan, suplementasi besi folat sebagai cara penanggulangan anemia serta pengetahuan - pengetahuan yang berkaitan dengan suplementasi besi folat sehingga prevalensi anemia pada kehamilan dapat menurun.

\section{DAFTAR PUSTAKA}

1. Badan Penelitian dan Pengembangan Kesehatan. Riset Kesehatan Dasar 2013. Jakarta: Kementerian Kesehatan RI;2013.

2. Peña-Rosas JP, De-Regil LM, Garcia-Casal MN, Dowswell T. Daily oral iron supplementation during pregnancy. Cochrane database Syst Rev. 2015;7(12).

3. Williams a L, Van Drongelen W, Lasky RE, Sanderson M, Lai D, Selwyn BJ,et al. Guideline: Daily iron and folic acidsupplementation in pregnant women[Internet]. World Health Organization.2012. Available from: http://apps.who.int/iris.bitstream/10665/77770/1/9789241501996_eng.pdf?ua $=1$

4. Kementerian Kesehatan RI. Profil Kesehatan Indonesia 2014. Jakarta: Kementerian Kesehatan RI; 2015.

5. Dinas Kesehatan Provinsi Jawa Tengah. Profil Kesehatan Provinsi Jawa Tengah Tahun 2014. Semarang: Dinas Kesehatan Provinsi Jawa Tengah; 2014.

6. Subagio HW. Hubungan antara Status Vitamin A dan Seng Ibu Hamil dengan Keberhasilan Suplementasi Besi. Semarang: Universitas Diponegoro; 2002.

7. Fatimah S, Hadju V, Bahar B, Abdullah Z. Pola Konsumsi dan Kadar Hemoglobin Pada Ibu Hamil di Kabupaten Maros, Sulawesi Selatan. Makara Kesehat. 2011;15(1):31-6.

8. CDC. Recommendations to prevent and control iron deficiency in the United States. Centers for Disease Control and Prevention. MMWR Recomm Rep. 1998;47(RR-3):1-29.

9. Rahmawati F. Kepatuhan Konsumsi Tablet Besi Folat Pada Ibu Hamil dan Faktor yang Mempengaruhi. Universitas Diponegoro; 2012.

10. Budiarni W. Hubungan Pengetahuan, Sikap, dan Motivasi dengan Kepatuhan Konsumsi Tablet Besi Folat pada Ibu Hamil. Universitas Diponegoro; 2012

11. Gibney MJ, Lanham-New SA, Cassidy A, Vorster HH. Introduction to Human Nutrition. Introduction to Human Nutrition. Sussex (United Kingdom): Wiley-Blackwell; 2009.

12. Grooper SS, Smith JL, Groff JL. Advanced Nutrition and Human Metabolism. 5th ed. California: Wadsworth; 2009.

13. Kathleen L, Escott-Stum S. Krause's, Food and Nutrition Therapy. 12th ed.Philadelphia: Saunders Elsevier; 2008.

14. Departemen Kesehatan R.I. Program Penanggulangan Anemia Gizi pada Wanita Usia Subur (WUS); (Safe Motherhood Project: A Partnership and 
Family Approach). Direktorat Gizi Masyarakat. Jakarta: Direktorat Jenderal Bina Kesehatan Masyarakat Depkes, 2001.

15. Hinderaker SG, Olsen BE, Lie RT, Bergsjø PB, Gasheka P, Bondevik GT, et al. Anemia in pregnancy in rural Tanzania: associations with micronutrients status and infections. Eur J Clin Nutr. 2002;56(3):192-9.

16. Linda J Harvey, Jack R Dainty, Wendy J Hollands, et al. Effect of high-dose iron supplements on fractional zinc absorption and status in pregnant women. American Journal of Clinical Nutrition, 2007 Vol. 85, No. 1, 131136.

17. Rahmawati F. Kepatuhan Konsumsi Tablet Besi Folat Pada Ibu Hamil dan Faktor yang Mempengaruhi. Universitas Diponegoro; 2012.

18. chultink W; van der Ree M. Low compliance with an iron-supplementation program: a study among pregnant women in Jakarta, Indonesia. Am J Clin Nutr 1993; 57: 135-9

19. Soekidjo Notoatmodjo. Ilmu perilaku kesehatan. Jakarta: Rineka Cipta. 2010. p.27-30,76

20. Besuni A, et. al. Nutrient Intake Relationship Forming Red Blood Cells with Hemoglobin Levels in Pregnant Women in Gowa. 000: 1 - 10.

21. James LG. Advanced Nutrition and Human Metabolism, 4th Edition. USA:Wadsworth. 2005. p.422. 
